RESEARCH PAPER

\title{
Relationship between Entrepreneurial Export Orientation and Export Entrepreneurship through Mediation of Entrepreneurial Capabilities
}

\author{
1Muhammad Saqib Nawaz* ${ }^{2}$ Masood ul Hassan
}

1 PhD Scholar, Department of Commerce, Bahauddin Zakaria University Multan, Punjab, Pakistan 2 Professor, Department of Commerce, Bahauddin Zakaria University Multan, Punjab, Pakistan

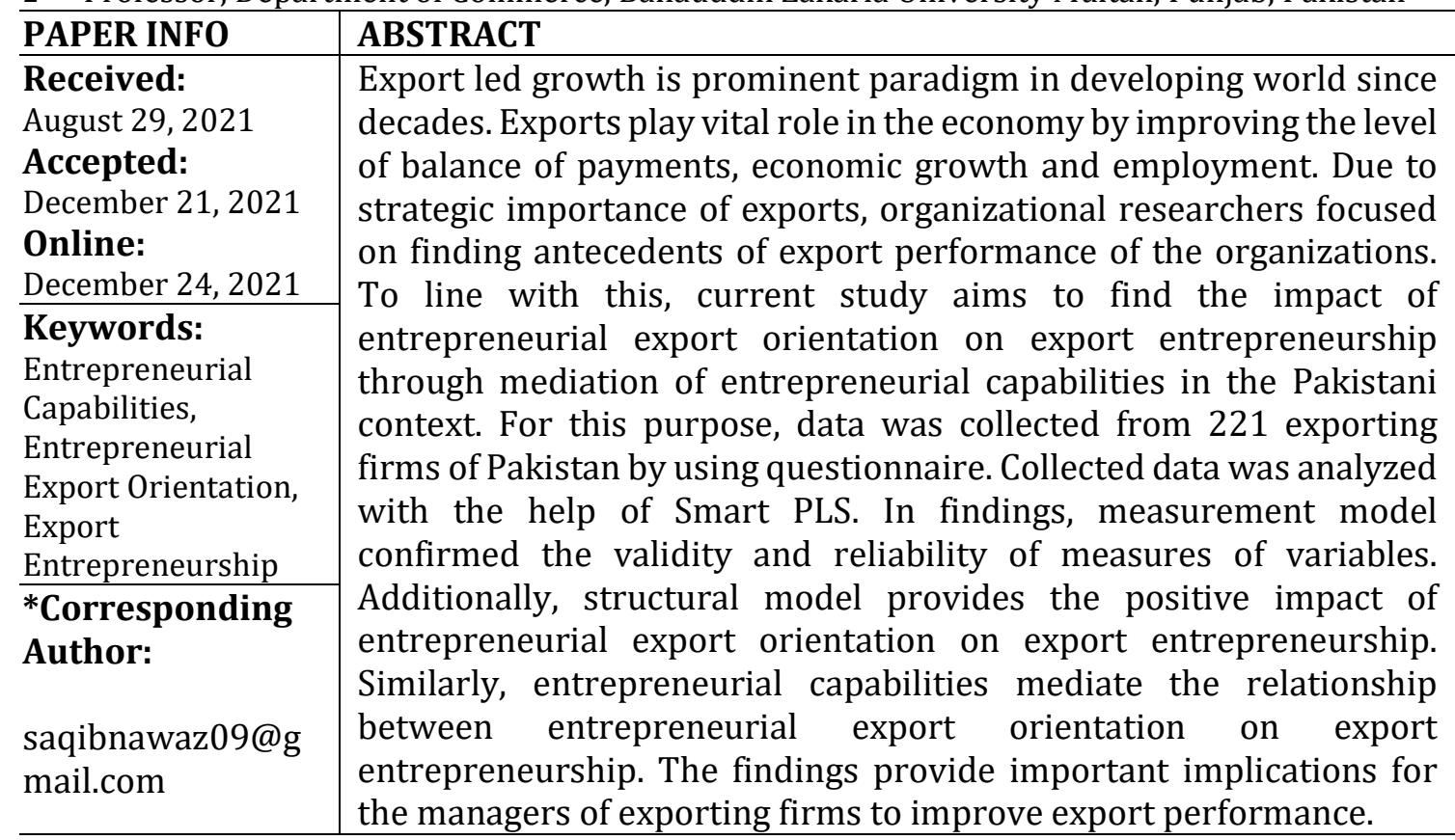

Introduction

Export led growth is prominent paradigm in developing world since decades. Exports play vital role in the economy by improving the level of balance of payments, economic growth and employment. Similarly, exports improve the level of foreign currency reserves and national productivity of a country (Chamberlain \& Kalaitzi, 2020; Hessels \& van Stel, 2011; Kalaitzi \& Chamberlain, 2020). However, export is the firm level phenomena. The level of exports is influenced by the success of individual firms in the export market (Cirera, Marin and Markwald, 2015; Liaqat \& Hussain, 2020). But, business organizations are facing turbulent business environment due to globalization and intense competition which is characterized by shorter life cycles and rapidly changing markets (Cosenz, Rodrigues \& Rosati, 2020; McGee, 2015). Most of the scholars are of the view that exporters have to be proactive and aggressive in the international market in order to exploit export opportunities in effective way (Bianchi \& Wickramasekera, 2013; Boso, Cadogan \& Story, 2012; Fernández-Mesa, \& Alegre, 2015; Santhosh, 2020; Tinashe Kahiya, \& Dean, 2014). Organizations which actively adapt and innovate according to changing trends tend to have higher export performance (Ibeh, 2004). In the same way, it is generally 
accepted that the ability to innovate is one of the main factors contributing to create competitive advantage, especially in terms of exports (Di Cintio, Ghosh \& Grassi, 2020; Lachenmaier and Wößmann, 2006). Similarly, according to Kuivalainen, Sundqvist, and Servais, (2007), increasing amount of evidence shows that entrepreneurial organizations are aiming at rapid internationalization despite the facts that they are having limited resources, small in size and early stage of development. Therefore, literature viewed entrepreneurship - in terms of innovativeness, pro activeness and risk taking - as key determinant of export performance (Huggins \& Thompson, 2015; Veglio \& Zucchella, 2015; Santhosh, 2020).

Considerable work has been done in the field of international entrepreneurship or more specifically, export entrepreneurship (Santhosh, 2020; Zahra \& George, 2017). However, this increased knowledge about export entrepreneurship is fragmented and does not provide a unifying theoretical direction to understand the process of export entrepreneurship (Keupp and Gassmann, 2009). Moreover, previous studies explaining the export behaviour have myopic view and considered limited factors to explain the export behaviour of the organization (Navarro-García, 2016).

This study aims to provide a comprehensive framework to explain the structure of export entrepreneurship. Strategic management literature provided the resource based view based on organizational internal dynamics. The RBV considers a firm as a unique parcel of valuable tangible and intangible resources, and these controllable resources and capabilities determine a firm's competitive advantage and performance in export market (Barney, Wright \& Ketchen, 2001; Katsikeas, Leonidou \& Morgan, 2000). However, export market is dynamic in nature and characterized by intense competition, and static nature of RBV limits its validity in dynamic export market. Dynamic capability perspective enriches the export strategy of the organization by providing the connection between internal dynamics of firm and external dynamic environment. Accordingly, companies develop organizational capabilities that will enable their survival in the long term and draw their organizational structure within the framework of these capabilities (Bowman \& Ambrosini, 2003; Teece, Pisano \& Shuen,1997). Therefore, following the international entrepreneurship literature, it is argued that entrepreneurial capabilities -ability to build, adapt, integrate and reconfigure resources \& knowledge- are essential in gaining the competitive advantage in the international market (Peiris, Akoorie, \& Sinha, 2012; Zehir, Köle, \& Yıldız, 2015). In other words, entrepreneurial capabilities trigger the export entrepreneurship in the competitive and dynamic international market.

Considering the fact that entrepreneurial capabilities are critical in the export performance, it is important to focus on the factors which enhance the entrepreneurial capabilities. According to (Boso, Annan, Adeleye, Iheanachor \& Narteh, 2016), entrepreneurial orientation provides the firm with organizational capabilities which are the source of export related performance. Specifically, Cadogan, Kuivalainen, \& Sundqvist (2009), put forwarded that export performance difference of firms is due to difference in entrepreneurial export orientations. It is obvious that it will be very beneficial for companies to develop an entrepreneurial capability to improve the export related performance in the international market. This study aims to build the connection between 
entrepreneurial export orientation, entrepreneurial capabilities and export entrepreneurship of the exporting firms of Pakistan. More specifically, this study aims to:

1. Find the impact of entrepreneurial export orientation on export entrepreneurship.

2. Find the mediating role of entrepreneurial capabilities in the relationship between entrepreneurial export orientation and export entrepreneurship.

\section{Literature Review}

\section{Export Entrepreneurship}

The term International Entrepreneurship was introduced by Morrow (1988) in a short article in which he discussed the opportunity to access the untapped foreign markets due to advancement in technology and increased cultural awareness. As the term suggest, amalgamation of international business and entrepreneurship provided an important research domain, namely international entrepreneurship (Oviatt \& McDougall, 2000). Despite of the adequate literature of international entrepreneurship, there is no single definition of the concept. Plethora of literature aims to answer the definitional issues of international entrepreneurship. International entrepreneurship is defined from different perspectives by using various but overlapping concepts. The process and behavioral approach are common and most widely used in explaining the international entrepreneurship.

According to Rialp, Rialp \& Knight (2014), the definition of Oviatt and McDougall (2005) is a comprehensive one and is most accepted and updated in the academic world. The authors defined as "... the discovery, enactment, evaluation, and exploitation of opportunities - across national borders - to create future goods and services" (p. 540). The export entrepreneurship is limited to the targeting the export related opportunities.

\section{Entrepreneurial Export Orientation and Export Entrepreneurship}

Literature of exporting provides plethora of studies which have used entrepreneurial dimensions in exporting (Samiee, Walters, \& DuBois, 1993; Simmonds and Smith, 1968). Samiee, Walters and DuBois (1993) explained the exporting from the perspective of innovative behaviour. According to them, firms with innovative behaviour have higher export performance. Innovation provides firms with competitive advantage in the international markets which results in to improved performance in the foreign market. Simmonds and Smith (1968) related the marketing innovation with the first export order of the internationalizing firm. Marketing innovation enables the organization to develop better marketing mix than competitors.

In the same way, Knight (2000) maintains that international entrepreneurship is related to risk taking and seeking opportunity by organizations or strong leaders. The above organizations' behavioural related definitions provide that main entrepreneurial dimensions -risk propensity, proactiveness and innovation- can therefore also applied to firm level. Risk-seeking behaviour is referred to readiness to allocate resources despite 
knowing the probability for failure may be high, while proactive behaviour is referred to the ability to foresee trends and act accordingly. Lastly, innovativeness is the propensity of supporting novel ideas, experiments and new practices.

Literature provides various insights of the relationship between entrepreneurial orientation and export performance. Entrepreneurial oriented exporters are more innovative than their competitors. The creative and novel solutions of exporters provide distinctive position to exporting organizations in the international market. International market is characterised by intense competition which demands innovativeness by firms in order to gain market share. Firms attract international customers by providing innovative solutions to customers. Similarly, innovative companies achieve the first mover advantage by offering innovative products and services in the export market. The first mover and pioneering advantage provide the firm with dominant position in export market, this advantage play vital role in improving the sales volume of exports (Shane \& Venkatraman, 2000). Similarly, Samiee, Walters, \& DuBois (1993) provided that innovative performance is associated with the export performance of organization.

Aggressiveness is another important dimension of entrepreneurial orientation. EO triggers aggressive behaviour of exporting organization in the export market. Firms with aggressiveness are willing to allocate more resources to the risky export projects. Similarly, aggressive firms are passionate to find export opportunities and willing to take risky projects. Additionally, entrepreneurial oriented firms show proactive behaviour in the export market. Proactiveness enables the organization to anticipate future requirements in the dynamic market and make strategies proactively. Export market is characterized by dynamic environment, and proactiveness provide competitive advantage in continuously changing environment. Zahra \& Garvis, (2000) put forwarded that proactiveness plays key role in gaining sustainable competitive advantage in the export market, especially in competitive and dynamic export market.

From the above discussion, it is being proposed

H1: Entrepreneurial export orientation has positive impact on export entrepreneurship.

\section{Mediation of Entrepreneurial Capability in the relationship between entrepreneurial export orientation and export entrepreneurship}

Although, the direct effect of entrepreneurial export orientation on export performance is alluring. The entrepreneurial orientation is a key intangible asset which reflects firm's behaviour, managerial philosophy and organizational practices that entrepreneurial in nature. The entrepreneurial orientation is generally reflected by dimensions of risk taking, proactiveness and innovativeness. All the three dimensions of entrepreneurial orientation provides the firm with entrepreneurial capability (Jantunen, Puumalainen, Saarenketo, \& Kyläheiko, 2005). The entrepreneurial orientation enables the organization to act proactively find, develop and exploit the opportunities in the environment. However, export market is dynamic in nature and characterized by intense competition, and static nature of RBV limits its validity in dynamic export market. 
In this regard, entrepreneurial capability is the key to survive in a turbulent and dynamic environment. It enables the organization to innovate and respond according to changing dynamics of environment. Dynamic capability perspective enriches the export strategy of the organization by providing the connection between internal dynamics of firm and external dynamic environment. Accordingly, companies develop organizational capabilities that will enable their survival in the long term and draw their organizational structure within the framework of these capabilities (Bowman \& Ambrosini, 2003; Teece, Pisano \& Shuen,1997). In other words, organizational resources are necessary in order to build the entrepreneurial capabilities for the development and pursuing for the opportunities (Wilson \& Martin, 2015). Entrepreneurial export orientation plays important role in building entrepreneurial capabilities in the organization, and these entrepreneurial capabilities leads to export performance. Similarly, Boso, Annan, Adeleye, Iheanachor and Narteh (2016) proposed in their framework that entrepreneurial export orientation is an important organizational resource in triggering organizational capabilities which in turn effect the level of export performance. Similarly, according to Chirico et al., (2011), entrepreneurial orientation is an important organizational resource which provides the firm with potential economic value and competitive advantage in the export market.

Resource based view and dynamic capability view also explain that intangible resources lead toward building the organizational capabilities such as entrepreneurial capabilities (Monteiro, Soares \& Rua, 2019). Considering the dynamic capability theory, the success of organization depends on the its ability of creation and accumulation of rare, valuable, and inimitable competencies and resources. The DCV posits that the competitive advantage of the firms is sustained only when the rare, valuable and perfect inimitable resources of organization are mobilized for the creation of rare and inimitable organizational capabilities (Hart, 1995). Similarly, Monteiro, Soares \& Rua (2019) Put forward that organizational resources are necessary for entrepreneurial capabilities such as finding and exploiting opportunities in the market. Therefore, it is argued that export market orientation affects the export entrepreneurship through the mediation of entrepreneurial capabilities.

H2: entrepreneurial capability mediates the relationship between entrepreneurial export orientation and export entrepreneurship.

\section{Material and Methods}

The study is quantitative in nature. Data of the study was collected from the exporting firms of Pakistan. Questionnaire was used to collect data from 221 exporting firms of Pakistan. The measures of the variables were adopted from previous studies. The entrepreneurial export orientation was measured by twelve items followed from the study of Knight and Cavusgil (2004). Similarly, entrepreneurial capabilities were assessed by using three items from the study of Zhang \& Tansuhaj \& McCullough (2009). Finally, Navarro-Garcia (2016) was followed for measuring the export entrepreneurship. Exporting firms were selected from all three categories - small, medium and large - in order to ensure the representation of all types of companies. 
Stratified random sampling was used to select the sample of the study. For this purpose, exporting firms were divided in to three strata - small exporting firms, medium exporting firms and large exporting firms. The collected data was analysed by using the Smart Pls. The validity and reliability of the measures were calculated before assessing the structural model.

\section{Results and Discussion Data Analysis}

The latest version of PLS-SEM (3.2.6) second generation multivariate was used for analyzing the data (Ringle et al., 2015). PLS-SEM is appropriate for building and testing the theory (Hair et al., 2016). In our study entrepreneurial orientation and entrepreneurial capability constructs are reflective, whereas export entrepreneurship is formative. In data analysis, first of all reliability and validity of the measures were assessed with the help of measurement model. And in the next step, path coefficient and the significance were estimated through structural model.

Reliability and validity of reflective measurement model (entrepreneurial orientation and entrepreneurial capability) was assessed by following criteria, indicator's reliability, internal consistency reliability, convergent validity, and discriminant validity. Whereas formative construct (export entreprenurship) is tested by outer weights and assess collinearity among indicators. The factor loading of the individual items should be assessed by calculating the outer loading of each item. The standard for retaining the item is having its value greater than 0.70 . In this study, outer loadings of all the items were higher than the standard value of 0.70 which provides that all measures were valid.

Secondly, Cronbach's Alpha was used to assess the internal consistency. The acceptable standard of Cronbach's Alpha is 0.70 or greater. In our findings, the value of Cronbach's Alpha is ranged from 0.731 to 0.906 , which provides that criterion of internal consistency was successfully met.

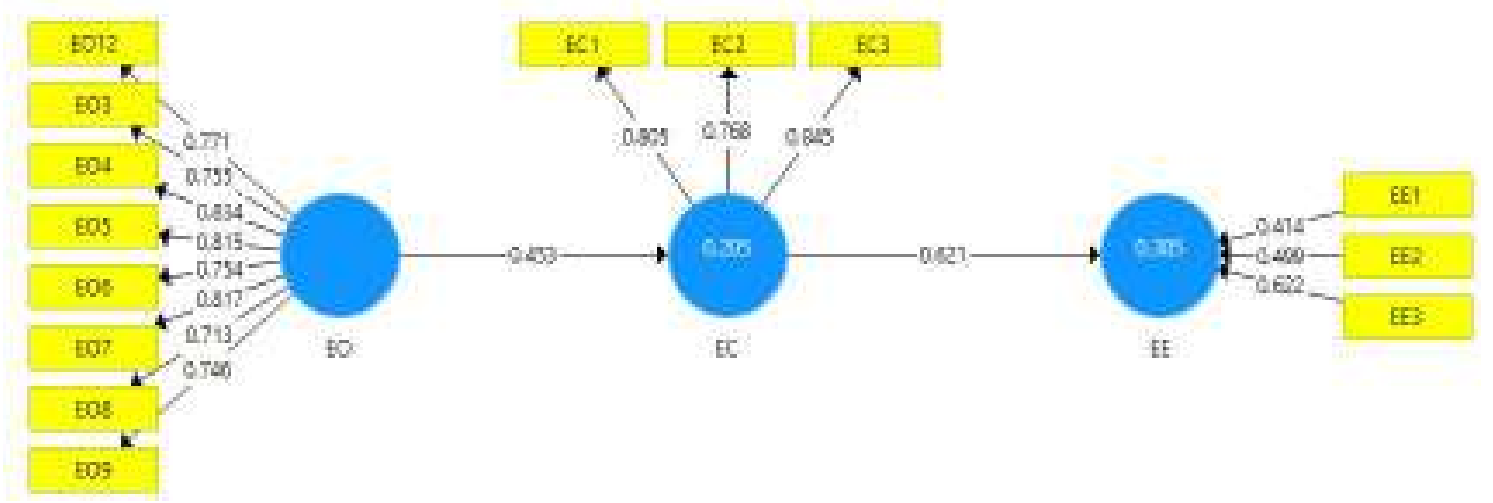

Figure I: Measurement Model

Furthermore, the composite reliability coefficient was used to find the internal consistency reliability of the measures. The standard acceptable value of composite reliability coefficient is 0.70 or greater. In this study, the composite reliability coefficient 
was found to be between 0.848 and 0.924 , which provides that study variables have adequate internal consistency.

Table I

Reflective Model assessment: Indicators reliability, internal consistency, Convergent Validity

\begin{tabular}{cccccc}
\hline & Items & Loading & AVE & Cronbach Alfa & $\begin{array}{c}\text { Composite } \\
\text { Reliability }\end{array}$ \\
\hline EC & EC1 & 0.805 & 0.650 & 0.731 & 0.848 \\
\hline & EC2 & 0.768 & & & \\
\hline EE & 0.845 & & & \\
\hline EE1 & 0.641 & & 0.924 \\
\hline EE2 & 0.607 & & \\
\hline EE3 & 0.694 & & \\
\hline E012 & 0.771 & 0.603 & & \\
\hline E03 & 0.755 & & & \\
\hline E04 & 0.834 & & & \\
\hline E05 & 0.815 & & & \\
\hline E07 & 0.754 & & \\
\hline E08 & 0.817 & & \\
\hline
\end{tabular}

Fornell and Larcker (1981) proposed the average variance extracted (AVE) for assessing the convergent validity. Convergent validity is explained as the degree to which a measure positively correlates with others measures of variables (Hair et al., 2014). The acceptable value of Average Variance Explained is greater than 0.50 (Hair et al., 2014). The findings of the study provides that AVE of the variables is greater than the acceptable value of 0.5 , which proved the convergent validity of the variables.

In addition to this, construct validity was assessed in order to find that each latent variable is distinct from remaining latent variables of the of study (Bagozzi et al., 1991). It was assessed by following the Fornell-Larcker test (Fornell and Larcker's, 1981; Hair et al. 2014) and heterotrait-monotrait (HTMT) ratio (Henseler et al., 2015) and through cross loadings.

Discriminant validity of the measures of this study was assessed by Fornell-Larcker test (Fornell and Larcker's, 1981), according to this criterion the square root of Average Variance Explained should be greater than the correlations among all studied variables. Results in the following table provide that square root of AVE value was greater than correlations among all studied variables therefore; discriminant validity of the measures was established.

Table 2

Discriminant Validity based on Fornell-Larcker Criterion 


\begin{tabular}{cccc}
\hline EC & 0.806 & & \\
\hline EE & 0.621 & & \\
\hline EO_ & 0.453 & 0.229 & 0.777
\end{tabular}

Note: AVE values shown in diagonals, and off-diagonals shows the correlations

HTMT was used to find the discriminant validity based on HTMT. This provides that if the value of HTMT is less than 1 then it means that construct is different from other constructs. In our study, the HTMT is 0.544 which proved the discriminant validity.

Table 3

Discriminant Validity based on HTMT Criterion

\begin{tabular}{cc}
\hline & 1 \\
\hline EC & \\
\hline EO & 0.544 \\
\hline
\end{tabular}

Finally, cross loadings were used to determine the discriminant validity. Loading of items should be more than cross-loading of items (Götz et al. 2010). The findings provide that all loadings are greater than the cross-loading as shown in table IV. Thus, measures of this study have standardized level of discriminant validity.

Table 4

Cross loading

\begin{tabular}{cccc}
\hline & EC & EE & EO \\
\hline EC1 & $\mathbf{0 . 8 0 5}$ & 0.510 & 0.445 \\
\hline EC2 & $\mathbf{0 . 7 6 8}$ & 0.496 & 0.302 \\
\hline EC3 & $\mathbf{0 . 8 4 5}$ & 0.494 & 0.336 \\
\hline EE1 & 0.398 & $\mathbf{0 . 6 4 1}$ & 0.211 \\
\hline EE2 & 0.377 & $\mathbf{0 . 6 0 7}$ & 0.107 \\
\hline EE3 & 0.431 & $\mathbf{0 . 6 9 4}$ & 0.143 \\
\hline E012 & 0.391 & 0.222 & $\mathbf{0 . 7 7 1}$ \\
\hline E03 & 0.343 & 0.157 & $\mathbf{0 . 7 5 5}$ \\
\hline E04 & 0.368 & 0.210 & $\mathbf{0 . 8 3 4}$ \\
\hline E05 & 0.367 & 0.210 & $\mathbf{0 . 8 1 5}$ \\
\hline E06 & 0.375 & 0.147 & $\mathbf{0 . 7 5 4}$ \\
\hline E07 & 0.381 & 0.197 & $\mathbf{0 . 8 1 7}$ \\
\hline E08 & 0.279 & 0.140 & $\mathbf{0 . 7 1 3}$ \\
\hline E09 & 0.279 & 0.119 & $\mathbf{0 . 7 4 6}$
\end{tabular}

First of all, in structural model, variance inflation factor was used to examine the collinearity issue. Collinearity assesses the level of correlation between the variables of the study (Hair et al., 2014). The standard of VIF is value below than 5, which means no collinearity is existed. The results of this study provides that VIF is 1 , which means collinearity does not exist in the data.

Secondly, hypothesized relations between the variables was assessed through path coefficient. The values of the path coefficient provides that entrepreneurial export 
orientation has positive impact on entrepreneurial capabilities and entrepreneurial capabilities has positive impact on export entrepreneurship. Additionally, bootstrap standard error was used to assess the significance of the relationship. The $p$ value of the relationships is less than 0.05 and $t$ value is greater than 1.96, therefore hypothesized relationships are significant.

In the following step, $\mathrm{R}$ square (coefficient of determination) was calculated to assess the level of variance explained in exogenous variables. The results provide that 20.5 percent of the variance in the entrepreneurial capability and 38.5 percent of the variance in the export entrepreneurship is explained by the endogenous variables.

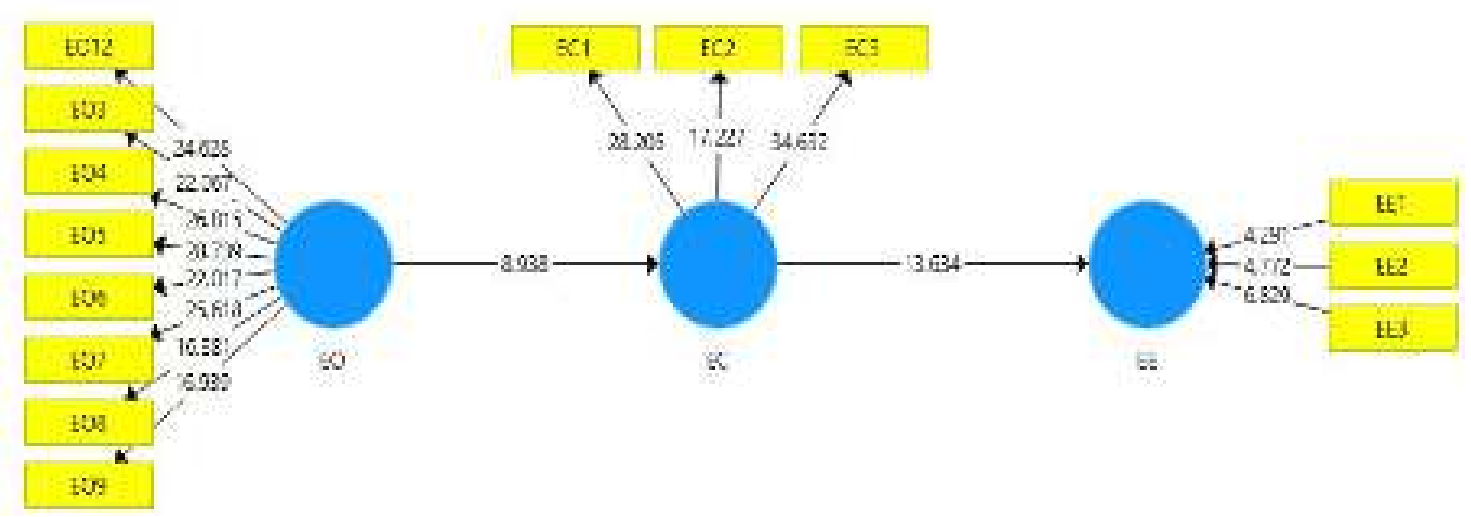

Figure II: Structural Model

Table 5

Summary of Structural Model Assessment

\begin{tabular}{ccccc}
\hline & $\mathrm{R}^{2}$ & T value & P value & Assessment \\
\hline EC & 0.205 & 4.466 & 0.000 & Weak \\
\hline EE $_{-}$ & 0.385 & 6.792 & 0.000 & Moderate \\
\hline
\end{tabular}

For mediation analysis we used model proposed by Hair et al., (2017) EC complementary mediation mediates the relationship between EO and EE. The finding shows that EC mediate the relationship between EO and EE.

Table 6

Hypothesis Testing

\begin{tabular}{|c|c|c|c|c|c|c|c|}
\hline \multirow{2}{*}{ Hypotheses } & \multirow{2}{*}{$\boldsymbol{\beta}$} & \multirow{2}{*}{$\begin{array}{c}\text { S. } \\
\text { error }\end{array}$} & \multirow{2}{*}{$\begin{array}{c}\text { t- } \\
\text { value }\end{array}$} & \multirow{2}{*}{$\begin{array}{c}P \\
\text { value }\end{array}$} & \multirow{2}{*}{ Decisions } & \multicolumn{2}{|c|}{ Confidence Interval } \\
\hline & & & & & & $2.50 \%$ & $97.50 \%$ \\
\hline $\mathrm{EC}->\mathrm{EE}_{-}$ & 0.621 & 0.046 & 13.634 & 0.000 & Supported & 0.525 & 0.707 \\
\hline EO $->$ EC & 0.453 & 0.051 & 8.938 & 0.000 & Supported & 0.351 & 0.544 \\
\hline EO $->E_{-}$ & 0.281 & 0.039 & 7.153 & 0.000 & Supported & 0.204 & 0.360 \\
\hline $\mathrm{EO}->\mathrm{EC}->\mathrm{EE}_{-}$ & 0.281 & 0.039 & 7.153 & 0.000 & Supported & 0.204 & 0.360 \\
\hline
\end{tabular}


Table 7

Effect Size $\mathbf{f}^{2}$

\begin{tabular}{ccc}
\hline Hypothesis & $\mathbf{f}^{2}$ & Effect Size \\
\hline EC $\rightarrow$ EE_ & 0.626 & L \\
\hline EO $\rightarrow$ EC & 0.258 & L \\
\hline
\end{tabular}

Moreover, it is important to find effect size ( $\mathrm{f}^{2}$ ) for significance of path coefficient for every independent variable on dependent variable (Hair et al. 2014). Effect size ( $\mathrm{f}^{2}$ ) is used to assess the variation in $\mathrm{R}$ square by eliminating specific independent variable from the model. Additionally, values of $\mathrm{f}^{2} 0.02,0.15$ and 0.35 are believed as small ( $\mathrm{S}$ ), medium $(\mathrm{M})$ and large (L) sizes respectively. Findings of this study provides that $\mathrm{f}^{2}$ are small.

Table 8

Predictive Relevance $\mathbf{Q}^{2}$

\begin{tabular}{cccc}
\hline Total & SSO & SSE & $\mathbf{Q}^{\mathbf{2}}(\mathbf{= 1 - S S E} /$ SSO) \\
\hline EC & 663.000 & 581.945 & $0.122 \mathrm{M}$ \\
\hline EE $_{-}$ & 663.000 & 564.177 & $0.149 \mathrm{M}$ \\
\hline
\end{tabular}

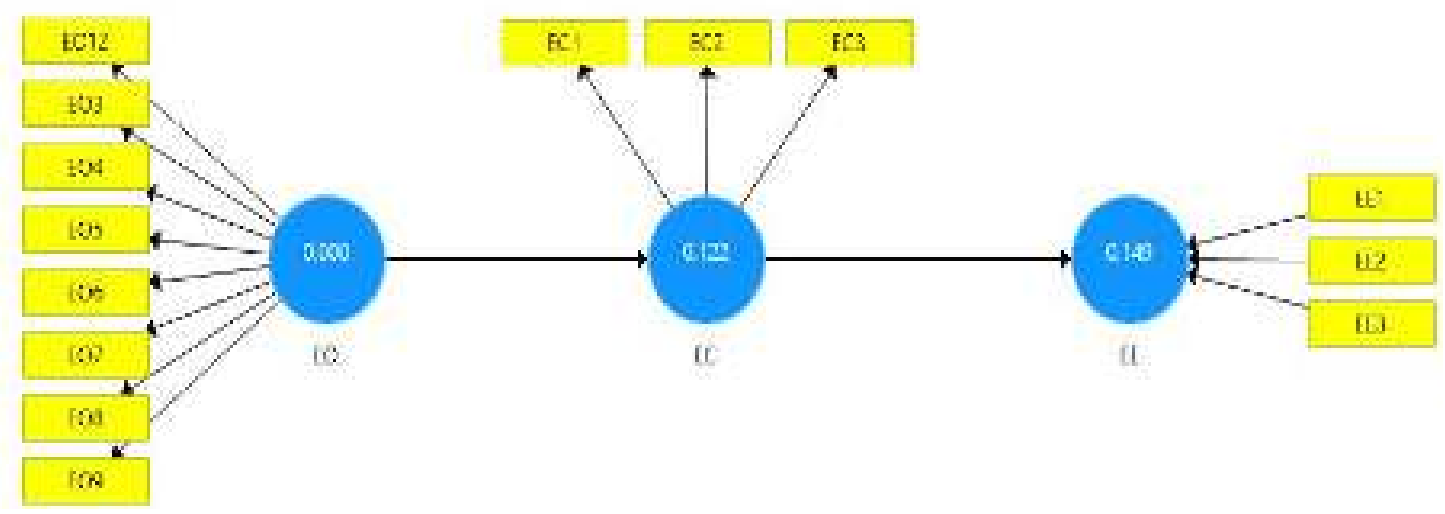

Figure III: Blindfolding test

Finally, predictive relevance $\mathrm{Q}^{2}$ was calculated to assess the quality of the model (Hair et al., 2014). For this purpose, Stone-Geisser's $Q^{2}$ is used (Geisser 1974; Stone 1976). The $\mathrm{Q}^{2}$ is calculated by taking the average of redundancy index of the endogenous latent variables (Hair et al. 2014).

\section{Conclusion}

This study found the relationship between entrepreneurial export orientation, entrepreneurial capabilities and export entrepreneurship. For this purpose, data was collected from exporting firms from Pakistan. The data was analysed with the help of Smart PLS through two models i.e. measurement model and structural model. The measurement model confirmed the validity and reliability of the measures of variables. Furthermore, 
structural model provides the relationship between the variables i.e. entrepreneurial export orientation, entrepreneurial capabilities and export entrepreneurship. The findings provide that entrepreneurial export orientation is positively and significantly associated with export entrepreneurship. Additionally, entrepreneurial capabilities mediate the relationship between entrepreneurial export orientation and export entrepreneurship.

More specifically, findings put forward that entrepreneurial nature of the firms facilitate in identifying and exploiting opportunities. In other words, entrepreneurial behaviour of firms provides the competitive position in the international market (Felzensztein, Ciravegna, Robson \& Amorós, 2015). The entrepreneurial orientation is characterized by innovativeness, proactiveness and risk taking. In particular, innovativeness leads to introduce new products and services in the international market. Introduction of new products and services attracts the attentions of customers and therefore increase the sales volume. Similarly, adoption of innovation provides new ways to access the market and compete with rival firms. Innovation also attracts the attentions of customers by providing innovative solutions to the problems of customers. In the same way, innovation provide the competitive advantage to firms by creating distinct position in the market (Covin and Miller, 2014). Additionally, proactiveness is significantly associated with export entrepreneurship. Firms which are proactive in finding and exploiting opportunities perform better in the international markets than reactive firms. This finding is in line with the results of study of Frishammar and Andersson (2009). The international market is characterised by turbulent environment and survival depends on ability to respond to changing environment proactively.

Furthermore, risk taking is positively associated with export entrepreneurship. Risk taking is the willingness to deploy resources in the projects having uncertain outcomes. International markets are uncertain and entry decisions require ability to take risk (Fernández-Mesa \& Alegre, 2015).

Similarly, the study provides the entrepreneurial export orientation play important role in building entrepreneurial capabilities in the firm which leads to superior performance in the export market. Therefore, the findings help in understanding the path through which entrepreneurial export orientation affect the performance in the export market. In other words, entrepreneurial capability is the missing link between entrepreneurial export orientation and export entrepreneurship.

Findings of study have practical and theoretical contributions. The results explain the export entrepreneurship framework in the Pakistani context. The findings are helpful for managers seeking increase in the export level. The study suggest that export is no more exclusively related with established large organizations. The new and small sized firms can enter and succeed in the international market by showing entrepreneurial behaviour.

\section{References}


Barney, J., Wright, M., \& Ketchen Jr, D. J. (2001). The resource-based view of the firm: Ten years after 1991. Journal of management, 27(6), 625-641.

Bianchi, C., \& Wickramasekera, R. (2013). An exploratory study of the factors enhancing and inhibiting export growth in the Chilean wine industry. Journal of International Food \& Agribusiness Marketing, 25(2), 85-102.

Boso, N., Annan, J., Adeleye, I., Iheanachor, N., \& Narteh, B. (2018). Examining the paths from export strategic orientations to export performance: The mediating role of export resource transformation capability. Thunderbird International Business Review, 60(2), 207-230.

Boso, N., Cadogan, J. W., \& Story, V. M. (2012). Complementary effect of entrepreneurial and market orientations on export new product success under differing levels of competitive intensity and financial capital. International Business Review, 21(4), 667681.

Bowman, C., \& Ambrosini, V. (2003). How the resource-based and the dynamic capability views of the firm inform corporate-level strategy. British journal of management, 14(4), 289-303.

Cadogan, J. W., Kuivalainen, O., \& Sundqvist, S. (2009). Export market-oriented behavior and export performance: quadratic and moderating effects under differing degrees of market dynamism and internationalization. Journal of international Marketing, 17(4), 71-89.

Chamberlain, T. W., \& Kalaitzi, A. S. (2020). Fuel-mining exports and economic growth: evidence from the UAE. International Advances in Economic Research, 26(1), 119-121.

Chirico, F., Sirmon, D. G., Sciascia, S., \& Mazzola, P. (2011). Resource orchestration in family firms: Investigating how entrepreneurial orientation, generational involvement, and participative strategy affect performance. Strategic Entrepreneurship Journal, 5(4), 307-326.

Cirera, X., Marin, A., \& Markwald, R. (2015). Explaining export diversification through firm innovation decisions: The case of Brazil. Research Policy, 44(10), 1962-1973.

Cosenz, F., Rodrigues, V. P., \& Rosati, F. (2020). Dynamic business modeling for sustainability: Exploring a system dynamics perspective to develop sustainable business models. Business Strategy and the Environment, 29(2), 651-664.

Covin, J. G., \& Miller, D. (2014). International entrepreneurial orientation: Conceptual considerations, research themes, measurement issues, and future research directions. Entrepreneurship Theory and Practice, 38(1), 11-44.

Di Cintio, M., Ghosh, S., \& Grassi, E. (2020). Direct or indirect exports: what matters for firms' innovation activities?. Applied Economics Letters, 27(2), 93-103. 
Felzensztein, C., Ciravegna, L., Robson, P., \& Amorós, J. E. (2015). Networks, entrepreneurial orientation, and internationalization scope: evidence from Chilean small and medium enterprises. Journal of Small Business Management, 53, 145-160.

Fernández-Mesa, A., \& Alegre, J. (2015). Entrepreneurial orientation and export intensity: Examining the interplay of organizational learning and innovation. International business review, 24(1), 148-156.

Fornell, C., \& Larcker, D. F. (1981). Evaluating structural equation models with unobservable variables and measurement error. Journal of marketing research, 18(1), 39-50.

Frishammar, J., \& Andersson, S. (2009). The overestimated role of strategic orientations for international performance in smaller firms.Journal of international entrepreneurship, 7(1), 57-77.

Götz, O., Liehr-Gobbers, K., \& Krafft, M. (2010). Evaluation of structural equation models using the partial least squares (PLS) approach. In Handbook of partial least squares (pp. 691-711). Springer, Berlin, Heidelberg.

Hair, J. F., Hult, G. T. M., Ringle, C. M., Sarstedt, M., \& Thiele, K. O. (2017). Mirror, mirror on the wall: a comparative evaluation of composite-based structural equation modeling methods. Journal of the academy of marketing science, 45(5), 616-632.

Henseler, J., Ringle, C. M., \& Sarstedt, M. (2015). A new criterion for assessing discriminant validity in variance-based structural equation modeling. Journal of the academy of marketing science, 43(1), 115-135.

Hessels, J., \& van Stel, A. (2011). Entrepreneurship, export orientation, and economic growth. Small business economics, 37(2), 255-268.

Huggins, R., \& Thompson, P. (2015). Local entrepreneurial resilience and culture: the role of social values in fostering economic recovery. Cambridge Journal of Regions, Economy and Society, 8(2), 313-330.

Jantunen, A., Puumalainen, K., Saarenketo, S., \& Kyläheiko, K. (2005). Entrepreneurial orientation, dynamic capabilities and international performance.Journal of International Entrepreneurship, 3(3), 223-243.

Kahiya, E. T., \& Dean, D. L. (2014). Export performance: multiple predictors and multiple measures approach. Asia Pacific Journal of Marketing and Logistics, 26(3), 378.

Kalaitzi, A. S., \& Chamberlain, T. W. (2020). Exports and economic growth: some evidence from the GCC. International Advances in Economic Research, 26(2), 203-205.

Katsikeas, C. S., Leonidou, L. C., \& Morgan, N. A. (2000). Firm-level export performance assessment: review, evaluation, and development. Journal of the Academy of Marketing Science, 28(4), 493-511. 
Keupp, M. M., \& Gassmann, 0. (2009). The past and the future of international entrepreneurship: a review and suggestions for developing the field.Journal of management, 35(3), 600-633.

Kevin, I. N. (2004). Furthering export participation in less performing developing countries. The effects of entrepreneurial orientation and managerial capacity factors. International Journal of Social Economics, 31(1-2), 94-110.

Knight, G. (2000). Entrepreneurship and marketing strategy: The SME under globalization. Journal of international marketing, 8(2), 12-32.

Knight, G. A., \& Cavusgil, S. T. (2004). Innovation, organizational capabilities, and the bornglobal firm. Journal of international business studies, 35(2), 124-141.

Kuivalainen, O., Sundqvist, S., \& Servais, P. (2007). Firms' degree of born-globalness, international entrepreneurial orientation and export performance. Journal of world business, 42(3), 253-267.

Lachenmaier, S., \& Wößmann, L. (2006). Does innovation cause exports? Evidence from exogenous innovation impulses and obstacles using German micro data. Oxford Economic Papers, 58(2), 317-350.

Liaqat, Z., \& Hussain, K. (2020). En route to the world: understanding firms that solely export. Economics Bulletin, 40(4), 2872-2886.

McDougall, P. P., \& Oviatt, B. M. (2000). International entrepreneurship: the intersection of two research paths. Academy of management Journal, 43(5), 902-906.

McGee, J. (2015). Breakpoint: The changing marketplace for higher education. JHU Press.

Monteiro, A. P., Soares, A. M., \& Rua, O. L. (2019). Linking intangible resources and entrepreneurial orientation to export performance: The mediating effect of dynamic capabilities. Journal of Innovation \& Knowledge, 4(3), 179-187.

Navarro-García, A. (2016). Drivers of export entrepreneurship. International business review, 25(1), 244-254.

Oviatt, B. M., \& McDougall, P. P. (2005). Defining international entrepreneurship and modeling the speed of internationalization. Entrepreneurship theory and practice, 29(5), 537-553.

Peiris, I. K., Akoorie, M. E., \& Sinha, P. (2012). International entrepreneurship: A critical analysis of studies in the past two decades and future directions for research. Journal of International Entrepreneurship, 10(4), 279-324.

Rialp, A., Rialp, J., \& Knight, G. A. (2014). International entrepreneurship: a review and future directions. The Routledge companion to international entrepreneurship, 27-48. 
Ringle, C., Da Silva, D., \& Bido, D. (2015). Structural equation modeling with the SmartPLS. Bido, D., da Silva, D., \& Ringle, C.(2014). Structural Equation Modeling with the Smartpls. Brazilian Journal Of Marketing, 13(2).

Samiee, S., Walters, P. G., \& DuBois, F. L. (1993). Exporting as an innovative behaviour: An empirical investigation. International Marketing Review.

Samiee, S., Walters, P. G., \& DuBois, F. L. (1993). Exporting as an innovative behaviour: An empirical investigation. International Marketing Review.

Santhosh, C. (2020). What affects the export entrepreneurship of SMEs?.Review of International Business and Strategy.

Simmonds, K., \& Smith, H. (1968). The first export order: a marketing innovation. European Journal of Marketing, 2(2), 93-100.

Teece, D. J., Pisano, G., \& Shuen, A. (1997). Dynamic capabilities and strategic management. Strategic management journal, 18(7), 509-533.

Veglio, V., \& Zucchella, A. (2015). Entrepreneurial firms in traditional industries. Does innovation matter for international growth?.Journal of International Entrepreneurship, 13(2), 138-152.

Venkataraman, S., \& Shane, S. (2000). The promise of entrepreneurship as a field of research. Academy of management review, 25(1), 217-226.

Wilson, N., \& Martin, L. (2015). Entrepreneurial opportunities for all? Entrepreneurial capability and the capabilities approach. The International Journal of Entrepreneurship and Innovation, 16(3), 159-169.

Zahra, S. A., \& Garvis, D. M. (2000). International corporate entrepreneurship and firm performance: The moderating effect of international environmental hostility. Journal of business venturing, 15(5-6), 469-492.

Zahra, S. A., \& George, G. (2017). International entrepreneurship: The current status of the field and future research agenda. Strategic entrepreneurship: Creating a new mindset, 253-288.

Zehir, C., Köle, M., \& Yıldız, H. (2015). The mediating role of innovation capability on market orientation and export performance: An implementation on SMEs in Turkey. ProcediaSocial and Behavioral Sciences, 207, 700-708.

Zhang, M., Tansuhaj, P., \& McCullough, J. (2009). International entrepreneurial capability: The measurement and a comparison between born global firms and traditional exporters in China. Journal of International Entrepreneurship, 7(4), 292-322. 